\title{
Urban policy and the rise of gated housing in post-socialist Poland
}

\author{
Dominika V. Polanska
}

Published online: 5 February 2014

(C) The Author(s) 2014. This article is published with open access at Springerlink.com

\begin{abstract}
The aim of this article is to investigate regulations regarding housing and spatial planning to determine the extent to which these have influenced the development of gated housing in Poland since 1989. The focus is on how government policy with regard to spatial planning and housing, together with the law on property and ownership, influences the emergence and development of gated forms of housing in the country. Legal regulation documents concerning issues of housing and spatial planning between 1990 and 2013 have been studied. The article argues that the liberal policies and legal regulation in the country is resulting in a disregard for spatial planning and housing, but also the lack of integrated urban policies. Existing spatial plans are of a consultative nature and bear no regulatory capacity, at the same time as housing programmes and spatial planning in the country is strongly in favor of private investors and new construction. All these shortcomings have created a differentiated housing market, one in which housing developers maximize their profits by constructing gated housing complexes, combined with a tendency among those who have the means to move to newly built housing behind gates. The long period of developer-friendly policies and governmental
\end{abstract}

D. V. Polanska ( $\bowtie)$

Centre for Baltic and East European Studies, Södertörn University, Alfred Nobels Allé 11, 14189 Huddinge, Sweden

e-mail: dominika.polanska@sh.se support of purchasers of new construction, have resulted in increased popularity of gated communities in Poland and their spread to many Polish cities.

Keywords Gated communities · Urban policy · Housing $\cdot$ Post-socialist cities $\cdot$ Poland

\section{Introduction}

Wherever it has occurred around the globe, the rise of enclosed and gated residential housing has aroused strong feelings. These forms of housing are not unique to the times in which we live; nor has it been determined that they emerge in specific types of societies. Already in ancient cities and during the Middle Ages, the existence of towns and settlements was dependent on the walls and gates that encircled them. The difference between today's gated residential housing and its precursors lies in the social characteristics of their inhabitants and their choices of housing. Ancient forms of gated cities encompassed whole towns and today's gated residential complexes encompass groups of people with same class characteristics having access to private services provided by their place of residence. Today's gated communities are in the words of Atkinson a sign of "a deepening physicality to existing levels of segregation" within cities (2008: 3). 
Gated communities have been observed on almost every continent since the mid-1990s, and their proliferation, forms and popularity have been studied by researchers in various disciplines, among others, geography, sociology, architecture, anthropology, economics and environmental psychology. Researchers of North American cities were the very first to pay special attention to the phenomenon of gating (see, for instance, Blakely and Snyder 1997; Low 2001; McKenzie 1994). They set the agenda and gave the phenomenon a definition, emphasizing the public restriction to the housing area secured by fences, walls and gates that, to some degree, include common resources available only to the residents (Blakely and Snyder 1997: 2). Since then, gated communities have been observed in other countries, including Spain, France and Portugal (Atkinson and Flint 2004; Glasze et al. 2006), South Africa (Jörgens and Landman 2007), China (Wu 2005) and Brazil (Caldeira 1996), to mention some.

Central and Eastern Europe also have their share of gated communities, although the intensity of the phenomenon varies among different countries (Hirt 2012). Furthermore, while the phenomenon of gating has intensified since the 1990s, academics have still not examined it in depth; the number of studies is limited, and the majority of them focus on postsocialist capital cities. Moreover, the phenomenon is not entirely new, since gated forms of housing were popular during Communism among highly placed representatives of the Communist Party (Stoyanov and Frantz 2006: 58). Despite this, gated housing in today's post-socialist countries is considered to be qualitatively different from the gated forms of housing that existed before 1989 due to the phenomenon's popularization and expansion to the upper and middle income households (cf. Atkinson 2008).

In the last few years, the number of scientific reports about gated housing developments in Central and Eastern Europe has been rising slowly but steadily from Sofia (Stoyanov and Frantz 2006; Hirt 2012); Moscow (Blinnikov et al. 2006; Lentz 2006); Budapest (Cséfalvay 2009); Bucharest (Negura 2009); Prague (Brabec and Sýkora 2009); Vilnius (Krupickaite and Pociūte 2009); Berlin and Budapest (Bodnar and Molnar 2010); Belgrade (Hirt and Petrovic 2011); Warsaw (Chabowski 2007; Gạsior-Niemiec et al. 2007; Gądecki 2007, 2009; Zaborska 2007; Mostowska 2009); Gdańsk (Polanska 2010a); Wrocław
(Kajdanek 2009); and Łódź (Tobiasz-Lis 2011). The situation in Poland is particularly interesting since the capital itself is home to over 400 gated communities (Gạdecki 2012), and the phenomenon's popularity has been observed in other cities all over the country such as Gdańsk, Gdynia, Płock, Bydgoszcz, Białystok, Katowice, Kraków, Radom, Poznań, and Olsztyn in the years 2003-2008 (Polanska 2010b). ${ }^{1}$ This article is a contribution to this limited field of knowledge on gated housing in Poland, with a focus on the national legislation in its understanding of the phenomenon.

The aim of this article is to investigate regulations regarding housing and spatial planning to determine the extent to which these have affected the development of gated housing in Poland since 1989. It focuses on how government policy on spatial planning and housing, together with the law on property and ownership, has influenced the emergence and development of gated forms of housing in the country.

In order to examine the Polish legal structure since 1989 and its effects on the urban landscape and, in particular, on the emergence of gated forms of housing in a more systematic way, a number of legal acts and regulations passed between 1990 and 2013 was studied. The acts were chosen for the study according to their relevance to urban policies, housing or spatial planning issues. Ownership regulations occupy an important role in the examination of the regulatory framework in the country and are supplemented in the analysis by means of previous studies on property rights regulations in Poland and other post-socialist countries. Furthermore, previous research findings on urban policies and urban planning in Poland, as well as statistics, are used to strengthen the arguments put forward. The interpretation of the legal regulation is

\footnotetext{
1 The majority of the gated communities built in Warsaw have been constructed in the 2000s (the first was built in 1997), in other words their popularity during the last 13-16 years have been enormous in the city. The largest one, Marina Mokotów consists of 4,500 dwellings. For comparative reasons we can mention that Budapest had 100 gated communities in 2007 (Csizmady and Csanadi 2009), Vilnius had 20 in 2008 (Krupickaite and Pociute 2009), Sofia had 80 in 2010 (Hirt 2012) and Prague had 57 gated housing complexes in 2008 and 16 other were being constructed (Brabec and Sýkora 2009). Unfortunately there is a lack of numerical data on the phenomenon as gated communities are usually not registered in official housing statistics. One needs to rely on research reports, and the ones presenting gating quantitatively in postsocialist societies are few.
} 
moreover influenced by the author's research on the subject and the empirical material gathered in order to understand the popularity of gating in Poland in the form of interviews with residents of gated communities, discourse analysis of newspaper articles on gated communities, and a questionnaire with the inhabitants of gated communities [for more information on material and methodology see Polanska (2010a, b, 2011, 2013)].

The article begins with a presentation of previous research on the topic and a clarification of the gaps in studies of post-socialist urban contexts, such as in the case of Poland. Next, the consequences of the systemic change in spatial planning in Poland are described together with the obstacles met along the way: the complicated process of restructuring property rights and the consultative nature of spatial plans. The results of the study are then presented, followed by a conclusion on the spatial and housing regulations influence on the proliferation of gated communities in the country.

\section{Previous research}

The systemic changes in former socialist countries have attracted the attention of many scholars since the 1990s. Researchers from various disciplines have studied post-socialist cities and the results of the systemic change reflected in their social, political and economic structure (for instance, see Węcławowicz 1998; Hamilton et al. 2005; Tsenkova and NedovićBudić 2006). The studies of urban policy and urban planning in these countries by some scholars resulted in conclusions on the lack of understanding and thorough research on the topic of urban policies in post-socialist countries (van Kempen et al. 2005; Simpson and Chapman 1999; Hirt and Stanilov 2009; Stanilov 2007).

A number of researchers who investigated property rights and ownership matters stressed the difficult nature of the privatization of property in post-socialist societies (Kim 2006; Marcuse 1996; Poznański 1993; Stark and Burszt 1998; Struyk 1996; Tosics 2005). Studies on privatization processes together with studies on urban issues such as urban planning and urban policy have, in the majority of cases, concentrated on the difficulties of implementing the new order. Most have focused on the shift to the new economic order and the decentralization of power, and not many have examined how these changes are manifested in the specific urban landscapes of these countries and in particular how they are connected to the phenomenon of gating and enclavement. The aim of this article is to fill in this gap and provide specific illustrations on how regulations regarding property and ownership interplay with the emergence and popularity of gated housing developments in the country.

While there have been many studies on gated communities, especially in the North and South American context, these forms of housing have still not been examined in depth in former socialist countries. Since the mid-1990s, Poland has taken the lead among these countries due to its constantly growing number of gated housing developments. Researchers at Warsaw University who recently initiated studies on the phenomenon of gating in the Polish capital have counted more than 200 gated communities in Warsaw. For instance, Chabowski (2007) focused on the typology of gated communities in Warsaw, distinguishing gated neighborhoods as follows: (1) those located closely to other gated neighborhoods, (2) neighborhoods enclosed some time after construction, (3) enclosed villa neighborhoods, (4) gated communities located in the middle of a block-house neighborhood, (5) detached "island neighborhoods," and (6) neighborhoods that will be fenced soon. Gądecki (2007), who studied the popular, professional and media discourse on gated communities in the country, learned that, in all three discourses, gated communities are portrayed as offering a lifestyle for the Polish middle class that reflects social and financial success, new aesthetics, stability and wellbeing. Zaborska (2007) investigated Warsaw residents' preferences with regard to the ideal housing and its environment and found that prospective buyers of new housing prefer safe and clean environments together with nice neighbors to fences or monitoring. Owczarek (2007) formulated questionnaires that would capture the social positions and social life of residents living behind gates and discovered that they are well educated and hold high cultural capital and relatively high incomes, but lack networks and frequent contacts with their neighbors. Mostowska (2009) studied Warsaw as well and argues that gated housing's popularity is connected to the provision of goods and services that the residents expect to find in 
gated housing. Gąsior-Niemiec et al. (2007) began with Warsaw and studied the proliferation of gated communities, particularly in the Ursynów district of the city. Their study, which is one of the most comprehensive in the Polish literature on the occurrence of gated communities in Warsaw, concluded that gated housing is a glocal phenomenon connected with economic, cultural and political aspects aimed at drawing physical boundaries in the city's landscape between different social groups. Studies of other Polish cities include Polanska's (2010a) survey on the forms of gated communities in Gdańsk along with their residents and their motives for moving to gated housing, Kajdanek's (2009) investigation of the situation in Wrocław with regard to suburban housing in the city and its forms of gating, and Tobiasz-Lis (2011) study of the role of security, prestige and tranquillity among gated housing residents and other residents of specific neighborhoods in Łódź.

According to the studies of Polish gated housing this kind of housing offers both lifestyles to the affluent but also provides them with goods and services that are inexistent in other forms of housing, especially those provided by the public authorities. Some of these studies mention urban policies in the country as influencing housing market development; however, none of them study this issue in depth. Therefore, the merit of this article lies in its ambition to more thoroughly investigate the influence of the housing and spatial planning regulation on the emergence and development of gated housing in Poland.

\section{The legal framework of housing and spatial planning in Poland after 1989}

The systemic change had great impact on the appearance of post-socialist cities and the planning and maintaining of urban spaces. A new scenario revealed itself to the observers of the changes going on in Central and East European cities after the fall of state socialism. A shift of power from the state to local governments and private actors became a reality. The responsibility for the development and maintenance of housing was no longer in the hands of the state (Struyk 2000: 17). In the case of Poland and many other postsocialist countries, this meant that the state lost its role as the central actor in spatial planning and chief investor in the housing structure of the country. Private investors, land rents and local governments re-entered the stage, which led to the change that some researchers of the shift referred to as "government to governance" (Nedović-Budić et al. 2006: 3; for a comparative description of the strategies of privatization in Poland, see Stark and Burszt 1998). In practice, this meant that in 1990, Polish local governments assumed responsibility for rent control and the housing stock (Statute on Territorial Self-Government), and that large parts of the property formerly owned by the state would be owned and managed by the local governments. Furthermore, in the 1994 Residential Lease and Housing Allowance Act, the local authorities were given the responsibility for housing policy, which in practice meant maintaining the municipal housing stock, setting rent levels, providing social housing and disbursing housing allowances. The introduction of self-governments in Poland resulted in municipalities gaining power over concrete spatial decisions, while on the central level, the Ministry of Infrastructure is responsible for the coordination and standardization of spatial planning in the country.

The development of the Polish housing and spatial planning regulation can be divided into two main periods. The first began in 1990 with the Constitution of the Republic of Poland and the initial introduction of laws and regulations that adhered to a market economy. The dividing line occurred in 1997 when a new constitution was enacted, and most of the acts introduced in the first part of the 1990s were amended when they were deemed insufficient. The first part of the 1990s was characterized by reactive measures in Polish urban policies, which answered to increasing problems in this sphere (Węcławowicz 2005: 69). New laws that dealt with the housing issues indirectly through the economic reforms were enacted or old laws were amended.

Polish housing policies are regulated by a list of legal acts and regulations on the national, international and European level. The strategic views on housing and spatial development of Polish policies were since 1990 formulated above all in the Constitution, but also in legal acts concerning the responsibilities of the municipal self-governments to provide housing to the citizens (Statue on Territorial Self-Government 1990), on the forms of support of housing construction (Act on Certain Forms of Support for Housing Construction 1995 and 2000), on the protection of tenants' rights and the municipal housing stock (Act on the 
Protection of Tenants' Rights and Management of Municipal Housing Stock 2001), on the financial support to the construction of social housing, protected housing, shelters and homes for homeless (Act on the Financial Support of Construction of Social Housing, Protected Housing, Shelters and Homes for Homeless 2006), on the financial support to families in purchasing own apartments (Act on the Financial Support to Families Purchasing their Own Apartments 2006), and on the housing cooperatives (Cooperatives Act 1994, 2000, 2003).

In 1997, Poland enacted a new Constitution, whose purpose was to separate and clarify the relationship between legal actors, which aimed at separating the legal relations between the state and municipalities in the country and introducing the system of selfgovernment. Moreover the new constitution indirectly established the framework for spatial planning in the country for the sections of the country's territorial structure, the definitions of property and ownership, and environmental protection (Jędraszko 2005: 58).

In the Polish Constitution there is an article that states the responsibility of public authorities to conduct politics that will "satisfy housing needs of the citizens, and in particular to counteract homelessness, to support construction of social housing and to encourage citizens actions directed towards the purchase of own apartment" (art.75, act 1). However the Constitution is of consultative nature towards public authorities and their policies and not of mandatory character.

There are also some international regulations that function as consultative documents in housing policies, but are in no way compulsory and these are the UN Human Rights Law, the UN Habitat Agenda signed in 1996, the European Social Charter signed in 1961 and the revised version in 2005 and the International Covenant on Economic, Social and Cultural Rights from 1966. The European Social Charter might function in different way than today, but Poland has not ratified it since the country signed the charter in 2005. The charter consists of the right of the family to social, legal and economic protection (art. 16), right to the protection against poverty and social exclusion (art. 30) and the right to housing (art. 31).

The Physical Planning Act of 1994 and the Spatial Planning and Management Act of 2003 represent two core legal acts with regard to spatial planning in Poland. The 1994 act initiated the formulation of the
"Study of the Conditions and Directions of Municipal Spatial Development" by the Polish municipalities and established the somewhat ambiguous rules on the creation of local spatial plans. ${ }^{2}$ Furthermore, through the 1994 act, local authorities were given even more freedom in physical planning and particularly in land allocation matters (rights that were first formulated in the Constitution). In practice, this act has led to the voluntary creation of local spatial plans by the municipalities; however, this was changed in the 2003 Spatial Planning and Management Act, when all municipalities were ordered to carry out obligatory studies of the conditions and directions of spatial planning (however not obligatory in construction decisions), but the formulation of the local spatial plans was left optional. In addition, under both acts, old spatial plans created during state socialism were abolished and at the same time, the last remains of the systematic and widespread tradition of spatial planning prior to 1990 were eliminated.

In May 2004 Poland accessed the European Union, and both preparations before the accession and its consequences have been evident in the country's aspirations in the field of spatial development. Urban issues have been in the forefront since the turn of the century, and the first state policy since the fall of the socialist regime was prepared in 2001 under the title National Spatial Development Policy Document. This policy document was the first of its kind since 1989 to take up the issue of spatial planning and urban policy, while focusing on integration with the European Union and the need to strengthen metropolitan areas in the country and especially the area around the capital. The next important document in Polish urban policies, National Development Plan 2004-2006, was released in 2002 and aimed at improving the population's standard of living by making use of the structural funds of the European Union. The plan included a section entitled National Strategy for Regional Development, which focused on the national

\footnotetext{
${ }^{2}$ In the Polish spatial planning law there are two main types of documents included: the Study of the Conditions and the Directions of Municipal Spatial Development and the Local Spatial Plans. The Study is an obligatory document that each municipality is required to formulate, but it is not compulsory in decisions on particular construction projects. However, if the municipality has prepared the other type of Local Spatial Plan, it is obligatory in construction decisions (but its formulation by the municipalities is not obligatory).
} 
labor market and stressed the importance of regional competitiveness and the modernization of technical and social infrastructures in the country, with the biggest focus on cities as junctions of growth (Węcławowicz 2005). In the Spatial Planning and Management Act of 2003, sustainable development was declared a foundation for spatial planning and management, and since then it has been the fundamental guiding principle in regulating spatial planning in the country. In spite of the extended legislation related to urban matters, as of today there is still no clearly defined national urban policy in Poland (OECD Territoral Reviews 2011). The development in the field of housing and spatial planning is directed by the above mentioned legal acts and lacks an integrated approach. The tendency since 1989 has instead been to formulate spatial and housing policies based on special Acts on selective matters such as highways, roads, foresting, the implementation of Euro 2012, the de-ruralization of land in urbanized areas, social housing, tenants' rights or support of homeownership, to name just a few. Even the most recent act on spatial planning, the Spatial Planning and Management Act (2003) failed to define governmental programs and more detailed plans on the application of the act (Table 1).

Furthermore, the current local spatial plans include different levels of spatial planning, which in turn makes them unique in the spatial planning tradition of Europe (Billert 2007: 2). Usually, there is a general plan that guarantees orderly and integrated spatial development alongside detailed plans for the realization of new construction within limited geographical areas. In Polish local plans, one finds both very general spatial plans and more specific and detailed plans. Moreover, what makes the local spatial plans even weaker is that, on a municipal level, they have no regulatory capacity and are formulated in documents of a more consultative nature. Moreover, at the time of the enactment of the Spatial Planning and Management Act (2003) most local spatial plans were outdated or invalid, which in turn brought complications to their implementation.

Additionally, neither the 1990 Constitution nor the 1997 version mention spatial planning as a crucial activity of the Polish public sector. Despite all the legal regulations, Polish spatial planning is charged with interpretations that favour landowners and investors without taking the interests of the broader strata of the population into account. Both in the legal structure and in practice, spatial planning is separated from socioeconomic planning. Neither in the fundamental act on Spatial Planning and Management Act (2003) nor in practice is spatial planning developed in agreement with the citizens concerned (Billert 2007: 3 ). The act has also been criticized for its vagueness in defining sustainable development and in its drawing on imprecise goals for spatial planning and management (Jędraszko 2005). Moreover, the courses of action included in the Physical Planning Act (1994) and the Spatial Planning and Management Act (2003) have failed. Both acts were intended to form a framework for regional plans and guarantee areas for public structural investments, but the plans were either never realized or fragmented in nature (Jędraszko 2005: 79). Out of 60 acts and 100 administrative acts that affect spatial planning in the country, none has been continually monitored, analyzed or introduced into the legislation concerning spatial planning.

The legal acts concerning housing are also in their current shape favouring either investors or households with middle- and higher incomes. Governmental programmes providing financial support for purchase of apartments (Act on the Financial Support to Families Purchasing Their Own Apartment) have been heavily criticized for their support of housing developers, not allowing financial support for singlefamily housing (only apartments) or purchase of apartments on the secondary market (only new construction).

As is evident in Fig. 1, the number of dwellings completed by co-operatives, the former providers of new housing in Polish cities, has been steadily declining since the beginning of the 1990s. Furthermore, it is also evident that the development has also been characterized by an increase in the number of dwellings completed for the purpose of selling or renting along with the growing number of dwellings built by private individuals.

The limitations on the power of municipalities to regulate spatial planning and to provide public housing spring from the imprecise and consultative nature of spatial plans in combination with strapped municipal budgets and the lack of funding on the national level. This in turn opens up opportunities for private actors to dictate the "rules" in the field of urban development. The reduction of control in spatial planning is closely related to the lack of resources on 
Table 1 Regulations on housing and spatial planning in Poland 1990-2013

Year $^{\mathrm{a}}$ Legal document $\quad$ Relation to urban development and housing

1990 The Constitution of the Republic of Poland

Statue on Territorial Self-Government

1991 Income Tax Act

1994 Physical Planning Act

1994 Building Law

1994 Housing Condominium Act

1994 Residential Lease and Housing Allowance Act

1994

2000

2003

1995

2000

1996

1997

Act on Housing Unit Ownership

2001

2003

2004

2005

2006

2010

2011

2001 National Spatial Development Policy Document

2002 National Development Plan 2004-2006

\section{Spatial Planning and Management Act}

Act on the Financial Support of Construction of Social Housing, Protected Housing, Shelters and Homes for Homeless 2004-2006
The supreme law of the country: introduction of selfgovernment, economic freedom and property rights, equality of private and public property, privatization of land and the housing stock

Decentralization of power from the state to regional and local authorities, clarification of legal relations between the state and the municipalities

Introduction of tax deductions for housing purposes

Elucidation of the responsibility for physical planning and land allocation issues by providing local authorities with more flexibility, simplifying building permit practices

Simplification of the construction regulations in the country

Clarification of the definition of condominiums and housing communities

Local governments responsible for spatial planning, rent regulation, social housing, housing allowances and the maintenance and development of the housing stock

Regulation of housing cooperatives distinguishing between three categories of cooperative rights: tenancy, ownership and ownership of a single-family house

Regulation of the rules on savings and the provision of contractual loans for housing

Regulation of real property of local and central governments

Clarification of civil and citizens' rights, clarification of the legal relations between different legal actors, full exploitation of property given only to Polish citizens and local authorities

Further definition of; individual ownership titles, rights and obligations of property owners and common property maintenance

Regulation of tenants' rights, municipalities responsibilities towards tenants, clarification of the rules on evictions and temporal premises. Unclear and therefore amended several times.

First document to touch upon spatial planning and urban policy on national level

National plan aiming at strengthening of the labour market, improving the living standards and regional competitiveness of larger cities and regions

Fundamental legal act regulating spatial planning in the country highlighting sustainable development

Regulation on financial help to those who aim at building, renovating or creating social housing, protected housing or housing for homeless. Co-financing of $20-40 \%$ of the investment costs 
Table 1 continued

\begin{tabular}{lll}
\hline Year $^{\mathrm{a}}$ & Legal document & Relation to urban development and housing \\
\hline 2006 & $\begin{array}{l}\text { Act on the Financial Support to Families Purchasing Their } \\
\text { Own Apartments 2006-2012 }\end{array}$ & $\begin{array}{c}\text { Provision of government granted funds covering 50 \% of the } \\
\text { cost of mortgage loan interest the first } 8 \text { years after } \\
\text { purchase } \\
\text { Provision of government granted funds for young people (up } \\
\text { to 35 years) purchasing their first apartment }\end{array}$ \\
\hline
\end{tabular}

a The year the legal act was promulgated and amended

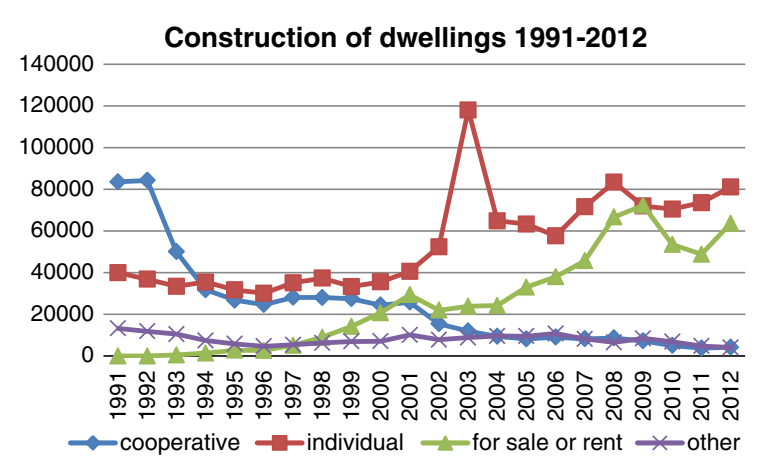

Fig. 1 Construction of dwellings in Poland in 1991-2012. Source Central Statistical Office 2013

the municipal level (Jędraszko 2005: 74). In some extreme cases, this lack has led to a situation in which the preparation of spatial plans is paid for by private investors. Another consequence of strapped municipal budgets is the selling off of municipal land and real estate to private investors in order to save money on the maintenance or earn additional money to add to the municipal budget. The winners of these regulations are housing developers and construction companies, which often purchase the land or buildings for small costs. The favourable position of investors, results in investments that are relatively free of control (as the spatial plans are merely consultative), thus opening the field for investments in the most profitable forms of construction (in the case of housing: gated communities).

To stimulate the housing market in Poland, policies formulated in the housing sphere in the period after the introduction of a market economy were almost exclusively created for the promotion of new construction (Merrill 2000). Rental housing was not prioritized after 1989, and the subsidies were given to buyers of new units, which in turn resulted in inequitable distribution and a situation whereby "higher-income Polish families have about a quarter of their new housing paid for by the government under the existing program" (Struyk 2000: 51). The four regulations that were passed in the first part of the 1990s: the Income Tax Act, the Physical Planning Act, the Building Law, and the Act on Certain Forms of Support for Housing Construction introduced tax deductions for housing purposes, simplified building permit practices and construction regulations, and regulated the rules on savings and the contractual loans for housing. All four contributed to the simplification and clarification of rules concerning the field of housing construction, thus creating beneficial opportunities for new construction and opening up opportunities for middle and higher income households to become homeowners.

\section{Obstacles along the way: the complicated restructuring of property rights}

The process of privatization in post-socialist countries was by no means problem-free (Marcuse 1996; van Kempen et al. 2005). Along with Czech Republic and Hungary, Poland has been recognized as the most successful country in the reform of property rights (Kim 2006: 214). The re-introduction/restatement of property rights and the active policy of privatization gave current housing occupants the opportunity to own their apartments and homes, often for a symbolic sum of money. As the new system was introduced, the restitution of property (both buildings and land) to prior owners was another complication that arose in the process of privatization in post-socialist societies (Tosics 2005). As a result of the new order, former owners of property and their descendents reclaimed their right, and a complicated process of ratification of the new owners began. Among the post-socialist countries, Poland has been singled out as one of the slowest countries to resolve the matter of restitution 
and compensation for the expropriation of property after 1989 (Karadjova 2004: 333). The complicated process of restitution of property in Poland covers the transfer of property rights that were seized or nationalized before (particularly during and after the Second World War) and under state socialism.

In the Constitution of the Republic of Poland, enacted in 1990, basic rights such as economic freedom, the guarantee of private property, and equality of private and public property were established. Article 7 of the Constitution defines property rights as transferable and inheritable possessions that can be freely disposed, limited only marginally by the principles of community life. The 1994 Cooperatives Act, which aimed at regulating housing cooperatives, distinguished among three categories of cooperative rights: tenancy, ownership and ownership of a singlefamily home. In this way, the question of ownership was further clarified. However, the complicated property relations that dated from before and under state socialism could not be solved in the first part of the 1990s. Furthermore, the adoption of the new constitution in 1997 did not succeed in solving the question of restitution in a satisfactory manner. Nor did the Act on Housing Unit Ownership, which served to further define individual ownership titles, the rights and obligations of property owners, and common property maintenance, solve the problem adequately. However, a law was enacted on the restitution of communal properties owned by Jewish religious communities prior to World War II in 1997. Moreoverm beginning in 1997, numerous outlines of the restitution legislation were prepared under Laszkiewicz, the Deputy Minister of the Treasury, on the restitution of property to private persons but none of them was passed in the parliament until the turn of the twenty-first century. Poland and Lithuania are the only countries that did not fully succeed in solving the question of restitution by the time they became members of the European Union in 2004. In 2001, the Polish parliament passed comprehensive re-privatization legislation, which only applied to Polish citizens who were "returning only a few properties to the owners and their inheritors but granting everyone a monetary compensation of $50 \%$ of the current value of the property in government bonds" to everyone who was entitled to it (Chodakiewicz and Currell 2003: 174). Nevertheless, this law was vetoed by President Kwaśniewski because of the consequences it would have on the budget. Over 20 enactments have been prepared on the matter of restitution in Poland, and until today none of them had been passed. In 2012 the government stated that claimants of property that has been taken over during socialism should use the Polish legal system to pursue their claims, at the same time making it clear that the ambition to pass a restitution or compensation law is inexistent.

The most difficult issues that were included in the passing of the restitution were those that dealt with how to weigh the rights of current users in relation to the rights of previous owners and whether to exercise restitution or compensation in such cases and if so, how to put a value on the property. This disarray resulted in important questions, such as the extent of the restitution in time, who should and should not be compensated and what kind of restitution should be exercised; to this day, they have not been resolved.

In many ways, the question of ownership is fundamental in the Polish situation and in particular in the development of gated forms of housing in the country. In many cases, the ambiguous ownership of buildings and land in the country as a result of the difficulties in determining the rightful owners that followed the systemic change hinders new investments and renovations of already existing housing stock. There are several examples on the undecided status of ownership, and the situation is most severe in the capital city, where it is clear that all landowners were expropriated under state socialism. Furthermore, the ambiguous ownership of buildings and land manifests itself in historical areas on the verge of decay as a result of the delay in the process of restitution to be followed by renovation and modernization (Węcławowicz 2005: 68; Polanska 2008). As both the housing stock built during socialism and the historical parts of Polish cities are "closed" to investments or enveloped by complicated ownership statuses, the investments in housing are dominated primarily by new construction in the cities' suburban areas (Kajdanek 2009). In Poland, suburbanization, or the migration of residents to suburban areas, is partly a result of the restoration of land rent and cheaper investment opportunities outside of the city centre along with far less complicated regulations regarding construction and ownership issues. Therefore, housing developers choose to invest in projects that are both more practical (and easier to bring to a close) and more profitable (charging extra for the securitization of the 
housing investments in times when gated communities are becoming more popular). All of the security devices that gated forms of housing require (ranging from fences, bars, reception desks to underground garages and monitoring) cost more, and the final price per square meter in such housing is considerably higher than in regular housing, thus creating a lucrative industry for the housing developers (Kajdanek 2009; Polanska 2010a). Moreover, there is also a demand for gated forms of housing among Poles as housing has become an important status marker in the Polish society, as a result of increasing socio-economic inequalities and differences in standard of old and new housing. In this context gated communities have become the 'symbol of exclusivity' (Polanska 2010b).

\section{Conclusions}

The aim of this article has been to examine the regulation regarding housing and spatial planning to determine the extent to which these have affected the development of gated housing in Poland since 1989. Poland has made rapid progress in the field of selfgovernment and property rights since the collapse of the socialist order at the beginning of the 1990s. It has also done some considerable development in the field of economy since its accession to the European Union in 2004 (OECD 2011) and throughout the financial crisis that hit Europe in 2008. However, there are some severe gaps when it comes to urban and housing policies and spatial planning in the country. The result of the acts and regulations established since 1989 is, above all, a housing market almost completely dominated by private actors. Even though the municipalities still own one tenth of the country's housing stock and the state and employers another $1.7 \%$, private persons own the majority of the stock (Instytut Rozwoju Miast 2008), and the situation is unlikely to change.

A common feature of the changes in post-socialist countries was that urban policies including housing and spatial planning issues, had to make way for economic policies. As a result, until 2005, Estonia, Latvia, Lithuania, Poland, Czech Republic, Hungary, Slovakia and Slovenia did not have explicit national urban policies to regulate development in urban areas (van Kempen et al. 2005: 6). In the case of Poland, the liberal policies and the belief-common in many postsocialist countries-that the market will regulate urban development, led to the neglect of spatial planning and the lack of a national urban policy until this day (cf. Sýkora 1994; Dimitrovska Andrews and Ploštajner 2000; Dimitrovska Andrews 2005; Węcławowicz 2005: 69). The most significant characteristics of Polish housing and spatial planning regulation have been the regulatory limitation of state intervention and developer-friendly policies in housing and spatial planning since 1989, until recently (2004 and forth) when financial support was introduced to constructors of housing for economically weakest parts of the population and purchasers/future homeowners. The long period of developer-friendly policies have resulted in increased popularity of gated communities among Poles and their spread to many Polish cities (Polanska 2013).

The privatization of the housing market and the construction business has had both positive and negative consequences for the Polish urban landscape. Most importantly, it has supplied the Polish housing market with new and different forms of housing, compared to the housing constructed under state socialism. The negative results can be seen in the neglect of integrated spatial planning, as today's Polish cities are characterized by contrasts and fragmentation that manifest themselves in the same ways as in other post-socialist cities, that is, in the degradation of urban areas, the underdevelopment of local city centres without a clear identity, and an increase in the social polarization of housing together with acute problems of revitalization (Dimitrovska Andrews 2005: 164).

The days of large-scale housing areas have definitely passed in Poland. Small-scale projects are accompanied by the development of building technologies, the introduction and proliferation of shopping malls around Polish cities, increased dependence on cars, suburbanization and social polarization followed by shifting demands. Furthermore, the restrictions with regard to construction on sites at the periphery of the cities and non-urbanized areas are few in number and easy to evade compared to the limitations placed on construction in the inner city, where the plans must, to some degree, be subordinated to complicated ownership issues and local plans, as well as to regulations laid down by local historic building conservators. Therefore, the lack of restrictions at 
the periphery, along with less complicated ownership conditions, has led to considerable urban sprawl.

It is at the same time obvious that the reduced amount of planning control and the increased role of market mechanisms can be observed not only in Polish cities but characterize development in many Central and East European cities as well (Tosics 2005; Hamilton et al. 2005; Pichler-Milanovich 2001). The development of gated residential housing is one of the many consequences of these laissez-faire policies and economic rationalism in Poland (see Atkinson 2008). Above all, in the case of Poland, the issues have included: the spatial plans' multiple nature, the lack of clear outlines and goals for housing and spatial planning at the national level, the separation of housing and spatial planning and socioeconomic activity, the lack of attention to the broader strata of the population in the planning and financing processes, and unclear ownership of buildings and land, together with the loopholes in the regulation of new construction. All these shortcomings have created a differentiated housing market, one in which housing developers freely choose their investments according to profit, combined with a tendency among those who have the means to move to newly built housing behind gates (cf. Polanska 2013; Hirt 2012).

Neither was the previous socialist system very successful in several spheres of urban policy, especially in housing policy. The results were: "persistent housing shortages, overcrowding, long waiting lists and deferred maintenance of multi-dwelling buildings stock, and, since 1980s, growing dissatisfaction with monotonous high-rise housing estates" (Pichler-Milanovich 2001: 152). In light of this, the new economic system promised better living. Were these promises fulfilled? Studies show that the privatization of the housing stock strengthened already existing inequalities in the distribution of housing, not only among different social groups but also in space, within cities and among the urban and rural areas of post-socialist countries (Struyk 1996; Pichler-Milanovich 2001). In addition, the increasing social polarization created demands for new and more exclusive types of housing among the wealthier segments of the Polish population (Polanska 2010b, 2013) and gated communities satisfied that demand by functioning as prestige markers (Jałowiecki and Łukowski 2007). In the case of Poland, the "winners" of the transformation moved to gated forms of housing as they spread throughout the country. As Polanska (2013) show the popularity of gated communities in Poland is a manifestation of the individual strategies prevalent in the Polish society as a result of economic changes, institutional failures (in particular in the field of housing planning and distribution) and cultural factors where the division between the public and the private is central. Gated communities are private places where individual interests in the closest group/family are cultivated at the expense of collective values. They are the places where some groups can make visible their resourcefulness and status in a society where the neo-liberal logic of individual success is very strong.

Some researchers have interpreted the period following the systemic transformation in post-socialist countries as "market failure" and "policy collapse," as illustrated by state withdrawal from the field of housing and urban development combined with the failure to create efficient and equitable housing reforms (Pichler-Milanovich 2001: 157). Others have pointed to the public-private partnerships as the main characteristics of the emergence of gated forms of housing, where construction costs are paid for by the private actors involved in the development and purchase of gated communities (Le Goix 2006). What is evident in the legal and regulatory framework of Poland is that the existing policies within the field of spatial planning and housing are too imprecise and need integration; that the present spatial plans function as consultative documents and hold no regulatory capacity; and that the policies are distinctly proconstruction, supporting only some specific groups, namely the investors and buyers of new construction.

Acknowledgments The author would like to thank the Centre for Baltic and East European Studies at Södertörn University for research funding and the reviewers for their constructive comments. I am also grateful to Sasha Tsenkova for fruitful cooperation on this special issue. It has been a pleasure to work with you.

Open Access This article is distributed under the terms of the Creative Commons Attribution License which permits any use, distribution, and reproduction in any medium, provided the original author(s) and the source are credited.

\section{References}

Atkinson, R. (2008). The politics of gating. European Journal of Spatial Development. http://www.nordregio.se/Global/ 
EJSD/Debate/debate080506.pdf. Accessed 11 September 2013.

Atkinson, R., \& Flint, J. (2004). Fortress UK? Gated communities, the spatial revolt of the elites and time-space trajectories of segregation. Housing Studies, 19(6), 875-892.

Billert, A. (2007). Planowanie przestrzenne a polityka -,,trzecia droga” do „trzeciego swiata”? In T. Ossowicz \& T. Zipser (Eds.), Urbanistyka w działaniu. Teoria i praktyka. Materiaty II Kongresu Urbanistyki Polskiej. Warszawa: Urbanista.

Blakely, E. J., \& Snyder, M. G. (1997). Fortress America. Gated communities in the United States. Washington DC: Brookings Institution Press.

Blinnikov, M., Shanin, A., Sobolev, N., \& Volkova, L. (2006). Gated communities of the Moscow green belt: Newly segregated landscapes and the suburban Russian environment. GeoJournal, 66(1), 65-81.

Bodnar, J., \& Molnar, V. (2010). Reconfiguring private and public: State, capital and new housing developments in Berlin and Budapest. Urban Studies, 47(4), 789-812.

Brabec, T., \& Sýkora, L. (2009). Gated communities in Prague. In C. Smigiel (Ed.), Gated and guarded housing in Eastern Europe. Leipzig: Selbstverlag des Leibniz-Instituts für Länderkunde.

Caldeira, T. (1996). Fortified enclaves: The new urban segregation. Public Culture, 8(2), 303-328.

Chabowski, R. (2007). Kwestia klasyfikacji i nazewnictwa osiedli zamkniętych w Warszawie. In B. Jałowiecki \& W. Łukowski (Eds.), Gettoizacja polskiej przestrzeni miejskiej. Warszawa: Wydawnictwo Naukowe Scholar.

Chodakiewicz, M. J., \& Currell, D. (2003). Restytucja: The problems of property restitution in Poland (1939-2001). In M. J. Chodakiewicz, J. Radzilowski, \& D. Tolczyk (Eds.), Poland's transformation: A work in progress. Charlottesville, VA: Leopolis Press.

Cséfalvay, Z. (2009). Demythologising gated communities in Budapest. In C. Smigiel (Ed.), Gated and guarded housing in Eastern Europe. Leipzig: Selbstverlag des Leibniz-Instituts för Länderkunde.

Csizmady, A., \& Csanadi, G. (2009). From housing estates to gated communitites. In C. Smigiel (Ed.), Gated and guarded housing in Eastern Europe. Leipzig: Selbstverlag des Leibniz-Instituts för Länderkunde.

Dimitrovska Andrews, K. (2005). Mastering the post-socialist city: Impacts on planning the built environment. In I. Hamilton, K. Dimitrovska, \& N. Pichler-Milanović (Eds.), Transformation of cities in Central and Eastern Europe. New York: United Nations University Press.

Dimitrovska Andrews, K., \& Ploštajner, Z. (2000). Local effects of transformation processes in Slovenia. Informationen zum Raumentwicklung, 7,(8), 435-449.

Gądecki, J. (2007). "Za murami”. Krytyczna analiza dyskursu. In B. Jałowiecki \& W. Łukowski (Eds.), Gettoizacja polskiej przestrzeni miejskiej. Warszawa: Wydawnictwo Naukowe Scholar.

Gądecki, J. (2009). Osiedla grodzone w Polsce-analiza dyskursu. Wrocław: Uniwersytet Wrocławski.

Gądecki, J. (2012). Gating Warsaw. Enclosed housing estates and the aestethics of Luxury. In M. Grubbauer \& J. Kusiak (Eds.), Chasing Warsaw. Socio-material dynamics of urban change since 1990. Frankfurt-am-Main: Campus Verlag.
Gąsior-Niemiec, A., Glasze, G., Lipok, D., \& Puetz, R. (2007). Grodzenie miasta: Casus Warszawy. Studia Regionalne $i$ Lokalne, 4(30), 5-30.

Glasze, G., Webster, C., \& Frantz, K. (2006). Private cities: Global and local perspectives. London: Routledge.

Central Statistical Office/Główny Urząd Statystyczny. (GUS). Budownictwo -wyniki dzialalnosci w 2007 r. www.stat. gov.pl. Accessed 10 August 2013.

Hamilton, I., Dimitrovska, K., \& Pichler-Milanović, N. (Eds.). (2005). Transformation of cities in Central and Eastern Europe. New York: United Nations University Press.

Hirt, S. A. (2012). Iron curtains. Gates, suburbs and privatization of space in the post-socialist city. Chichester: WileyBlackwell.

Hirt, S. A., \& Petrovic, M. (2011). The Belgrade Wall: The proliferation of gated housing in the Serbian capital after socialism. International Journal of Urban and Regional Research, 35(4), 753-777.

Hirt, S. A., \& Stanilov, K. (2009). Twenty years of transition: The evolution of urban planning in Eastern Europe and the former Soviet Union, 1989-2009. Human settlements global dialogue series. Nairobi: UN HABITAT.

Instytut Rozwoju Miast. (2008). Informacje o mieszkalnictwie-wyniki monitoringu za 2007 r. Krakow. http://www. mi.gov.pl/2-48203f1e24e2f-1790054.htm. Accessed 8 September 2013.

Jałowiecki, B., \& Łukowski, W. (Eds.). (2007). Gettoizacja polskiej przestrzeni miejskiej [Ghettoization of Polish Urban Space]. Warszawa: Wydawnictwo Naukowe Scholar.

Jędraszko, A. (2005). Zagospodarowanie przestrzenne w Polsce- drogi i bezdroza regulacji ustawowych. Warszawa: Wydawnictwo Platan.

Jörgens, U., \& Landman, K. (2007). Gated communities in South Africa. In G. Glasze, C. Webster, \& K. Frantz (Eds.), Private cities: Global and local perspectives. London: Routledge.

Kajdanek, K. (2009). Is suburban housing in Wrocław gated and why? In C. Smigiel (Ed.), Gated and guarded housing in Eastern Europe. Leipzig: Selbstverlag des Leibniz-Instituts för Länderkunde.

Karadjova, M. (2004). Property restitution in Eastern Europe: Domestic and international human rights law responses. Review of Central and East European Law, 29,(3), 325-363.

Kim, A. M. (2006). The role of property rights reforms in Warsaw's housing market. In S. Tsenkova \& Z. NedovićBudić (Eds.), The urban mosaic of post-socialist Europe. Heidelberg: Physica-Verlag.

Krupickaite, D., \& Pociūte, G. (2009). Gated and guarded housing in Lithuania. In C. Smigiel (Ed.), Gated and guarded housing in Eastern Europe. Leipzig: Selbstverlag des Leibniz-Instituts för Länderkunde.

Le Goix, R. (2006). Walling in the city: Gated communities as predators of public resources. In G. Glasze, C. Webster, \& K. Frantz (Eds.), Private cities: Global and local perspectives. London: Routledge.

Lentz, S. (2006). More gates, less community? Guarded housing in Russia. In G. Glasze, C. Webster, \& K. Frantz (Eds.), Private cities: Global and local perspectives. London: Routledge. 
Low, S. M. (2001). The edge and the centre: Gated communities and the discourse of urban fear. American Anthropologist, 103(1), 45-58.

Marcuse, P. (1996). Privatization and its discontents: Property rights in land and housing in the transition in Eastern Europe. In I. Szelenyi (Ed.), Cities after socialism. Oxford: Blackwell Publishers.

McKenzie, E. (1994). Privatopia: Homeowner associations and the rise of residential private government. New Haven and London: Yale University Press.

Merrill, S. (2000). Home purchase in the Visegrad Countries: The case of Poland. In R. J. Struyk (Ed.), Homeownership and housing finance policy in the Former Soviet Bloc. Costly populism. Washington DC: The Urban Institute.

Mostowska, M. (2009). Provision of private services and enforcing neighbours' behaviour in one of Warsaw's gated neighbourhoods. In C. Smigiel (Ed.), Gated and guarded housing in Eastern Europe. Leipzig: Selbstverlag des Leibniz-Instituts för Länderkunde.

Nedović-Budić, Z., Tsenkova, S., \& Marcuse, P. (2006). The urban mosaic of Post-Socialist Europe. Heidelberg: Physica-Verlag.

Negura, O. (2009). Residential ensembles in "hypermodern times". A case study of their aspirations in Bucharest. In C. Smigiel (Ed.), Gated and guarded housing in Eastern Europe. Leipzig: Selbstverlag des Leibniz-Instituts för Länderkunde.

OECD Territoral Reviews. (2011). Urban Policy reviews. Poland.

Owczarek, D. A. (2007). Życie społeczne zamkniętych osiedli Warszawskich- czyli co się dzieje za bramą? [The social life of gated communities in Warsaw- in other words what is going on behind the gates?]. In B. Jałowiecki \& Łukowski, W. (Eds.), Gettoizacja polskiej przestrzeni miejskiej [Gettoization of Polish Urban Space]. Warszawa: Wydawnictwo Naukowe Scholar.

Pichler-Milanovich, N. (2001). Urban housing markets in Central and Eastern Europe: Convergence, divergence or policy 'Collapse'. European Journal of Housing Policy, 1(2), 145-187.

Polanska, D. (2008). Decline and revitalization in post-communist urban context-a case of the Polish city of Gdansk. Communist and Post-Communist Studies, 41(3), 359-374.

Polanska, D. V. (2010a). The emergence of gated communities in post-communist Poland. Journal of Housing and the Built Environment, 25(3), 295-312.

Polanska, D. V. (2010b). Gated residential housing and the construction of social class markers in post-socialist societies - the case of Poland. International Journal of Space and Culture, 13(4), 421-435.

Polanska, D.V. (2011). The emergence of enclaves of wealth and poverty. A sociological study of residential differentiation in post-communist Poland. Acta Universitatis Stockholmiensis, New series 50.

Polanska, D. V. (2013). Gated housing as a reflection of publicprivate divide. Polish Sociological Review, 1(181), 87-102.
Poznański, K. Z. (1993). Restructuring of property rights in Poland: A study in evolutionary economics. East European Politics and Societies, 7(3), 395-421.

Simpson, F., \& Chapman, M. (1999). Comparison of urban governance and planning policy: East looking west. Cities, 16(5), 353-364.

Stanilov, K. (2007). The post-socialist city: Urban form and space transformations in Central and Eastern Europe after socialism. Dordrecht: Springer.

Stark, D., \& Burszt, L. (1998). Postsocialist pathways. Transforming politics and property in East Central Europe. Cambridge: Cambridge University Press.

Stoyanov, P., \& Frantz, K. (2006). Gated communities in Bulgaria: Interpreting a new trend in post-communist urban development. GeoJournal, 66(1), 57-63.

Struyk, R. J. (1996). Housing privatization in the Former Soviet Bloc to 1995. In I. Szelenyi (Ed.), Cities after socialism. Oxford: Blackwell Publishers.

Struyk, R. J. (2000). A regional policy report. In R. J. Struyk (Ed.), Homeownership and housing finance policy in the Former Soviet Bloc: Costly populism. Washington DC: The Urban Institute.

Sýkora, L. (1994). Local urban restructuring as a mirror of globalization processes: Prague in the 1990s. Urban Studies, 7(31), 1149-1166.

Tobiasz-Lis, P. (2011). Osiedla grodzone w Łodzi. Przyczyny i konsekwencje zjawiska. Space - society - economy, Wspótczesne przemiany środowiska mieszkaniowego wybrane problemy, 10(II), 99-114.

Tosics, I. (2005). City development in Central and Eastern Europe since 1990: The impacts of internal forces. In I. Hamilton, K. Dimitrovska, \& N. Pichler-Milanović (Eds.), Transformation of cities in Central and Eastern Europe. New York: United Nations University Press.

Tsenkova, S., \& Nedović-Budić, Z. (Eds.). (2006). The urban mosaic of post-socialist Europe. Heidelberg: PhysicaVerlag.

Van Kempen, R., Vermeulen, M., \& Baan, A. (Eds.). (2005). Urban issues and urban policies in the new EU countries. Aldershot, Hampshire: Ashgate.

Węcławowicz, G. (1998). Social polarization in post-socialist cities: Budapest, Prague and Warsaw. In G. Enyedi (Ed.), Social change and urban restructuring in Central Europe. Budapest: Akademia Kiado.

Węcławowicz, G. (2005). Poland. In R. van Kempen, M. Vermeulen, \& A. Baan (Eds.), Urban issues and urban policies in the new EU countries. Aldershot, Hampshire: Ashgate.

Wu, F. (2005). Rediscovering the 'gate' under market transition: From work-unit compounds to commodity housing enclaves. Housing Studies, 20(2), 235-254.

Zaborska, K. (2007). Przestrzeń miejska- dobro wspólne czy ziemia niczyja. In B. Jałowiecki \& W. Łukowski (Eds.), Gettoizacja polskiej przestrzeni miejskiej. Warszawa: Wydawnictwo Naukowe Scholar. 